\title{
Effects of different feeding methods on neuropeptide nesfatin-1 and irisin in turkeys
}

\author{
F. Caf ${ }^{1}$, H. Inci ${ }^{2 \#} \&$ T. Ayasan ${ }^{3}$ \\ ${ }^{1}$ Vocational School of Technical Sciences University of Bingol 1200, Bingol, Turkey \\ 2 Department of Animal Science, Faculty of Agriculture, Bingöl University, Bingöl 12000, Turkey \\ ${ }^{3}$ Osmaniye Korkut Ata University, Kadirli Academy of Applied Sciences, Osmaniye/Turkey
}

(Submitted 25 March 2020, Accepted 19 November 2020, Published 3 March 2021)

\author{
Copyright resides with the authors in terms of the Creative Commons Attribution 4.0 South African License. \\ See: http://creativecommons.org/licenses/by/4.0/za \\ Condition of use: The user may copy, distribute, transmit and adapt the work, but must recognize the authors and the South African \\ Journal of Animal Science.
}

\begin{abstract}
In this study, the effects of different methods of feeding turkeys on the neuropeptide nesfatin-1 and the hormone irisin were evaluated. A total of 90 turkeys were distributed to three treatment groups, namely T1: conventional system, T2: 50\% feed and pasture, and T3: pasture. There were 30 birds in each group with three random replications. The birds were fed for 18 weeks. At the end of the study, blood was collected from 10 birds of each group. Plasma nesfatin-1 and irisin levels were measured with an enzyme-linked immunoassay. The nesfatin-1 levels of male turkeys in T1, T2, and T3 were $0.76 \pm 0.1 \mathrm{ng} / \mathrm{m}, 0.41 \pm 0.1$ $\mathrm{ng} / \mathrm{ml}$, and $1.24 \pm 0.2 \mathrm{ng} / \mathrm{ml}$, respectively. Nesfatin-1 levels in the female turkeys in T1, T2 and T3 were 0.53 $\pm 0.07 \mathrm{ng} / \mathrm{ml}, 1.18 \pm 0.3 \mathrm{ng} / \mathrm{ml}, 1.32 \pm 0.1 \mathrm{ng} / \mathrm{ml}$, respectively. The irisin levels in the male turkeys in T1, T2, and T3 were $575.93 \pm 42.5 \mathrm{pg} / \mathrm{ml}, 188.39 \pm 1.8 \mathrm{pg} / \mathrm{ml}$, and $607.54 \pm 24.1 \mathrm{pg} / \mathrm{ml}$, respectively. Irisin levels of the female turkeys in T1, T2 and T3 were $603.20 \pm 42.2 \mathrm{pg} / \mathrm{ml}, 241.42 \pm 18.4 \mathrm{pg} / \mathrm{ml}$, and $399.29 \pm 21.5$ $\mathrm{pg} / \mathrm{ml}$, respectively. Because nesfatin-1 is involved in regulating food intake, food intake by turkeys might differ, depending on the management system. Different management systems might also alter irisin secreation because it can be induced by exercise.
\end{abstract}

Keywords: endocrine, food intake, management system

\#Corresponding author: hakaninci2565@hotmail.com

\section{Introduction}

Living organisms must consume enough energy to survive. Suppression of feed intake and the energy it supplies are important factors that can affect the nutrition, reproduction, growth, and other metabolic functions of living things negatively (Cameron et al., 1993; Steiner et al., 2003). Because Turkey imports feed resources and pays in foreign exchange, efforts to find feed resources that are cheap and are not used directly in human nutrition have gained momentum (Blake, 1993). Feed expenses constitute approximate $30 \%$ of the total cost of production for turkeys (McDougal, 2020). Thus, it is necessary to know how and how much to feed turkeys.

The hypothalamus is the main centre in which bodyweight-energy balance control is regulated (Spiegelman \& Flier, 2001; Juge-Aubry et al., 2003). The lateral hypothalamus controls hunger, whereas the ventromedial hypothalamus controls satiation. These two areas work in collaboration and with other regions of the brain to maintain energy balance (Richard \& Baraboi, 2004). The hypothalamus controls energy balance by evaluating the stimulating or suppressive signals received from the body systems (Havel, 2004; King, 2005). The neuropeptide nesfatin- 1 is secreted from the hypothalamus and by the nervous system and peripheral tissues (Unniappan \& Peter, 2005; Volkoff et al., 2005), and is responsible for the regulation of appetite (Oh-l et al., 2006; Shimizu et al., 2009; Gonzalez et al., 2010; Stengel et al., 2012) and body temperature (Könczöl et al., 2012). The nucleobindin 2 gene (NUCB2) codes for a hormone that consists of 396 amino acids and has a high amino acid sequence homology in rats, mice, and human beings (GarciaGaliano et al., 2010). Of the 396 amino acids of NUCB2, the first 82 amino acids constitute nesfatin-1, amino acids 85-163 constitute nesfatin-2, and amino acids 166-396 constitute nesfatin-3 (Oh-I et al., 2006).

Irisin is a hormone composed of 111 amino acids with secretion induced by exercise (Boström et al., 2012). Irisin is an adipomyocine that reportedly stimulates thermogenesis by transforming white adipose 
tissue to brown in mammals. It is synthesized and released by many tissues with its main sources being skeletal muscle and adipose tissue (Aydin, 2014; Arhire et al., 2019).

There is limited information pertaining to irisin in non-mammalian invertebrates, including birds. For the first time, Li et al. (2015) identified irisin in chickens and indicated that it had a high degree of sequence homology with the human (97\%), mouse (97\%), and zebra fish (80\%) hormones. Li et al. (2015) demonstrated that avian irisin was abundantly expressed in muscle, heart, pituitary gland, ovary, and brain, and in small amounts in adipose tissue, kidney, lung, testis, and the small intestine.

Nesfatin-1 and irisin are potentially effective in regulating hunger, nutrient intake, energy metabolism, bodyweight, and glucose balance. Although the effects of nesfatin-1 on humans and rats have been studied in more detail, there are few studies on poultry (e.g. Cisse, 2012; Shousha et al., 2015; Banerjee \& Chaturvedi, 2015) and even less is known about the effects of irisin in birds. Previously, it was shown that turkeys fed in confinement, those that were pastured, and those in hybrid systems differed in their patterns of growth (Inci et al., 2020). Therefore, these systems were evaluated for effects on circulating levels of nesfatin-1 and irisin.

\section{Material and Methods}

This research was carried out in the poultry unit of the Department of Zootechnics, Faculty of Agriculture, Bingöl University. Bingöl University Experimental Ethics Committee approved the project (No 2014/09-09/03).

Day-old turkey chicks $(n=90)$ were distributed to three treatment groups, namely T1: conventional system, T2: $50 \%$ feed and pasture, and T3: pasture. The 30 birds that were allocated to each treatment were randomly divided into three replications of 10 birds each. The concentrate feeds that was used in T1 and T2 (Table 1) was formulated to meet the approximate needs of turkeys according to NRC (1993) norms. During the first eight weeks of their lives all poults were fed a starter diet inside. Two 60-watt bulbs were used to light the experiment room. Heat was provided by the thermostatically controlled electric stoves. The room was divided into three equal compartments that were bedded to a depth of $8 \mathrm{~cm}$ with wood shavings and straw. Plastic feeders with wire grills were placed in the compartments, and hygienic measures were used to ensure the health of the animals. When the poults were eight weeks old, the treatments were imposed. T1 continued to be fed concentrated feed indoors. T2 had access to pasture for eight hours a day and received $50 \%$ of concentrate feed that the T1 group consumed. T3 grazed on pasture and were not given supplemental feed. The pasture comprised alfalfa, grass, sainfoin, vetch, wheat and barley. It was sampled while it was grazed with the samples being used for nutrient analysis. The forage was $87 \%$ dry matter and contained $14.85 \%$ crude protein, $2.4 \%$ crude fat, $31.5 \%$ crude fibre, and $9.6 \%$ crude ash. The calculated energy content of the forage was $1900 \mathrm{kcal} / \mathrm{kg} \mathrm{DM}$. The trial ended when the birds were 18 weeks old.

Table 1 Protein and energy values of concentrate feeds prepared for turkey poults according to their age

\begin{tabular}{lccc}
\hline Stage of growth & Age, weeks & Protein, \% & Energy kcal $/ \mathrm{kg}$ dry matter \\
\hline Starter & $0-8$ & $26-28$ & $2800-2900$ \\
Grower & $9-14$ & $20-23$ & $2900-3000$ \\
Finishing & $15-17$ & $16-19$ & $3000-3200$ \\
\hline
\end{tabular}

At slaughter, blood was aspirated into an evacuated tube containing an anticoagulant. It was then centrifuged for 10 minutes at $3000 \mathrm{rpm}$ to obtain the plasma. The plasma was transferred to 2-ml Eppendorf tubes and kept frozen at $-80^{\circ} \mathrm{C}$ until it was analysed (Price et al., 2007; Stengel et al., 2009). Nesfatin-1 plasma levels in turkeys were measured with a commercial kit (LSBio Inc., Seattle, Washington, USA, catalogue number LSF10671), with a measurement interval of $0.78 \mathrm{ng} / \mathrm{mL}$ to $50 \mathrm{ng} / \mathrm{mL}$. The intra- and interassay coefficients of variation and sensitivity for nesfatin-1 were lower than $5.3 \%$ and $7.1 \%$, respectively. The ELISA assays of nesfatin- 1 had a sensitivity of $<0.78 \mathrm{ng} / \mathrm{mL}$. Irisin plasma levels were measured with a commercial kit (LSBio Inc., Seattle, Washington, USA; catalogue no LS-F13185), with a measurement interval of $78 \mathrm{pg} / \mathrm{mL}$ to $5000 \mathrm{pg} / \mathrm{mL}$. The intra- and inter-assay coefficients of variation and sensitivity for Irisin were lower than $5.1 \%$ and $8.1 \%$, respectively. The ELISA assays of Irisin had a sensitivity of $<78$ $\mathrm{pg} / \mathrm{mL}$. 
The Kolmogorov-Smirnov $Z$ test was applied to the data to test for normality. An analysis of variance was used to assess the significance of treatment and gender effects. The critical value for significance was set at $P=0.05$. Results were presented as mean \pm SE.

\section{Results and Discussion}

The effects of the feeding methods on nesfatin- 1 levels were significant, but the pattern of the effects differed by gender (Figure 1). Average effects of gender on nesfatin-1 were not detectably different. For the male turkeys, nesfatin-1 levels differed $(P<0.05)$, with the highest levels in T3 $(1.24 \pm 0.2 \mathrm{ng} / \mathrm{ml})$ and lowest levels in T2 $(0.41 \pm 0.1 \mathrm{ng} / \mathrm{ml})$ with T1 being intermediate $(0.76 \pm 0.1 \mathrm{ng} / \mathrm{ml})$. The difference between T2 and T3 was significant, whereas T1 was not significantly different from the other treatments. In contrast, the nesfatin-1 levels of female turkeys in T2, T3, and T1 were $1.18 \pm 0.3 \mathrm{ng} / \mathrm{ml}, 1.32 \pm 0.1 \mathrm{ng} / \mathrm{ml}$, and $0.53 \pm 0.07$ $\mathrm{ng} / \mathrm{ml}$, respectively. The nesfatin- 1 level of female turkeys that had been subjected to T3 was significantly higher than those that were subjected to $\mathrm{T} 1$.

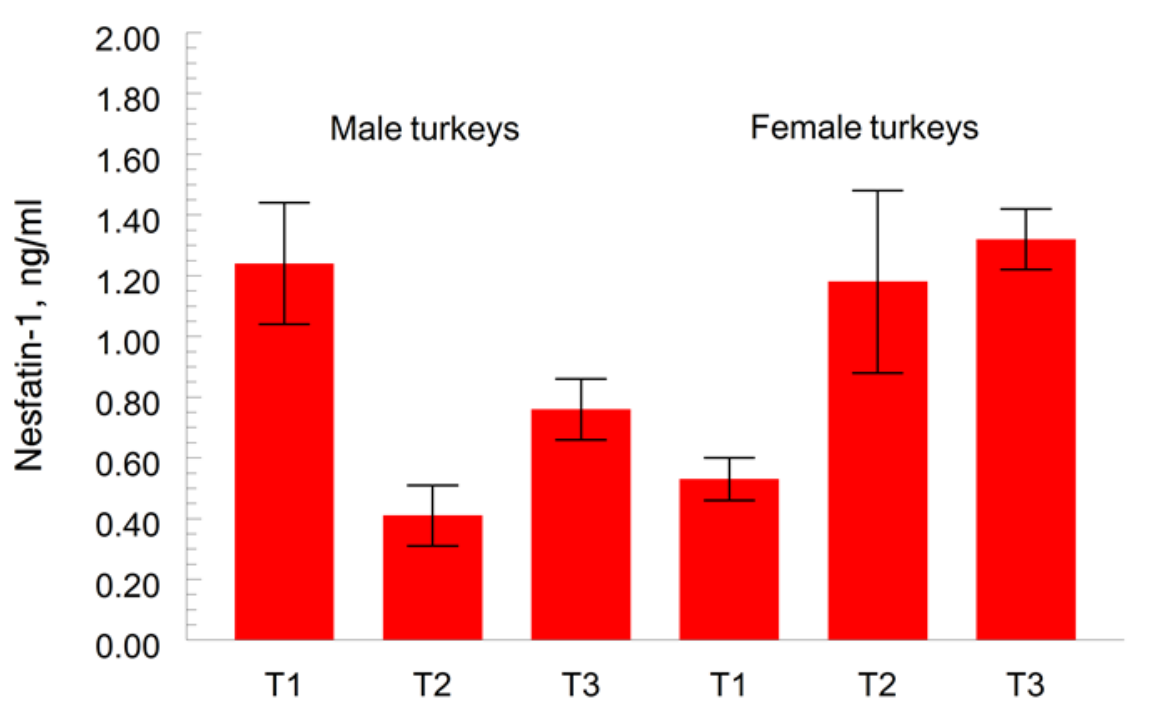

Figure 1 Nesfatin-1 levels of male and female turkeys allotted to a conventional indoor system (T1), fed $50 \%$ of the same concentrate feed as T1 with access to pasture (T2), and those reared only on pasture (T3)

Effects of feeding methods on irisin levels were significant and, as with nesfatin-1, the pattern of effects differed by gender (Figure 2). For the male turkeys, the highest levels of irisin were found in T3 $(607.54 \pm 24.1 \mathrm{pg} / \mathrm{ml})$ and significantly lower levels T2 $(188.39 \pm 1.8 \mathrm{pg} / \mathrm{ml})$ with T1 again being intermediate $(575.93 \pm 42.5 \mathrm{pg} / \mathrm{ml})$, but not different from T3. In contrast, the irisin levels of female turkeys were highest in T1 $(603.20 \pm 42.2)$ and lower in T2 $(241.42 \pm 18.4)$ and T3 $(399.29 \pm 21.5 \mathrm{pg} / \mathrm{ml})$. Thus, the irisin levels were depressed for poults in T2 as opposed to those in T1 and T3. The irisin levels found in male turkeys were on average only slightly higher than those found in females. 


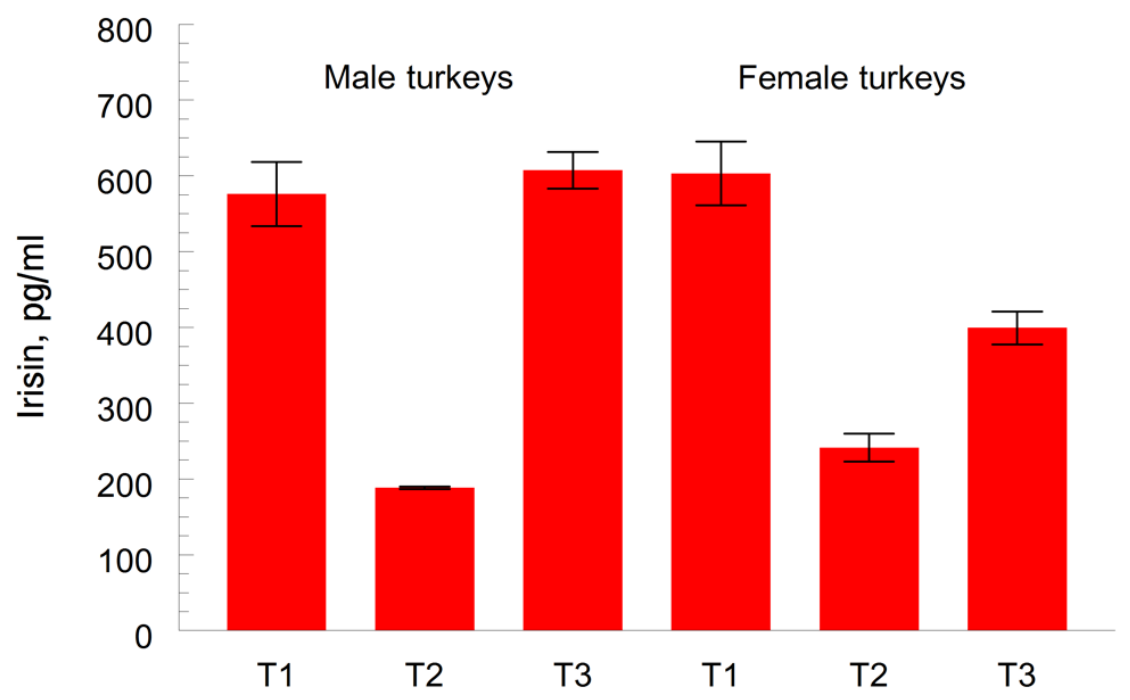

Figure 2 Irisin levels of male and female turkeys allotted to a conventional indoor system (T1), fed $50 \%$ of the concentrate feed of T1 with access to pasture (T2), and those reared only on pasture (T3)

The hypothalamus plays an important role in the brain as the production site of food intake regulatory factors. More importantly, this area integrates the peripheral and central signalling factors to regulate food intake and long-term bodyweight (Çatlı et al., 2014). The nesfatin-1 neuropeptide is a signal that controls appetite in rodents, humans, and fish, resulting in reduced food intake, and can pass through the blood-brain barrier (Price et al., 2007). Likewise, nesfatin-1 has physiological connections at the central nervous system level when regulating nutrient uptake and energy homeostasis in pigs (Varricchio et al., 2014) and rats (Wernecke at al., 2014). Plasma nesfatin-1 levels have been shown to rise as the weight increases (Aydin, 2013; Mirzaei et al., 2014). However, in the current study, the plasma nesfatin-1 levels of the turkeys fed with pasture were higher than those of $\mathrm{T} 1$. The turkeys that could access pasture also showed a marked reduction of growth rate at eight weeks, with only the T3 group showing full recovery to the level of T1 by the 16th week (Inci et al., 2020). Haghshenas et al. (2014) reported that exercising would be likely to decrease nutrient intake, weight gain and fat deposition by increasing nesfatin-1 levels. In a study investigating the serum nesfatin-1 levels in patients with disease-related weight loss, it was found that nesfatin-1 levels were lower in the patients with weight loss compared with those with no weight loss, suggesting that weight loss may lower serum nesfatin-1 levels (Cetinkaya et al., 2013). Peripheral concentrations of nesfatin-1 have been found to be significantly negatively correlated with body fat ratio, body fat weight, and blood sugar (Tsuchiya et al., 2010). Significant relationships between fat percentage and circulating nesfatin-1 were observed in obese and morbidly obese subjects (Mirzaei et al., 2014). In obese subjects, with lower nesfatin1 concentrations, calorie, carbohydrate and protein intakes were even higher, also implying a relationship between nesfatin-1, food consumption and body composition. Further, there may be a feedback mechanism in which the composition of the diet affects the circulating level of nesfatin-1 (Mohan et al., 2014).

Despite these physiological effects in a variety of species, nesfatin-1 expression and physiology have not been studied thoroughlt in birds. Banerjee and Chaturvedi (2015) reported the localization and expression of nesfatin-1 in the testes, ovaries and shell glands of Coturnix coturnix japonica. They emphasized its role in regulating reproduction, and stated that the relationship between appetite control and feed intake through energy balance was important. In the present study, circulating (plasma) nesfatin-1 levels were determined in turkeys fed with various methods. In addition, it was found that plasma nesfatin-1 levels were gender independent ( $\mathrm{Li}$ et al., 2010). The difference in nesfatin-1 levels between male and female turkeys was found to be non-significant $(P=0.10)$.

Irisin secretion by skeletal muscle cells is induced by exercise in mice and humans, and mildly increased irisin levels in the blood cause an increase in energy expenditure in mice without additional activity or food intake (Böstrom et al., 2012). This increase was from irisin, which caused browning of white adipose tissue and increased metabolism. In T3 irisin levels were high, presumably because of their increased level of physical activity in the more novel environment. However, the heaviest and presumably most sedentary turkeys in this study were in T1 (Inci et al., 2020), and this group had high levels of irisin levels in both males and females. Thus, another explanation could be that these birds had a greater amount of body fat because $28 \%$ of the circulating irisin was secreted from adipose tissue (Roca-Rivada et al., 2013). This observation is 
supported by Stengel et al. (2009), who found that circulating irisin levels in obese individuals were higher than those in individuals with normal weight.

Previous studies have not found a relationship between gender and irisin levels in obese people (Lopez-Legarrea et al., 2014; Blüher et al., 2014). However, in this study the difference between male and female poults in irisin levels bordered on being significant $(P=0.054)$.

\section{Conclusions}

The feeding methods imposed in this study affected the levels of nesfatin- 1 and irisin, with some indication of an interaction between feeding method and gender. Curiously, the hybrid system in which pasture was supplemented with concentrate feed did not consistently produce results that were intermediate between the two extreme feeding methods. However, detailed studies are needed to understand the mechanisms of action of nesfatin- 1 and irisin in poultry and whether they can affect animal health and the balance between feed consumption and fattening performance.

\section{Acknowledgements}

The authors would like to thank Central Laboratory Research and Application Centre, Bingol University

\section{Authors' Contributions}

$\mathrm{HI}$ and $\mathrm{FC}$ contributed to the project idea, design and execution of the study. $\mathrm{FC}$ and $\mathrm{HI}$ were in charge of laboratory analyses. TA and CF were responsible for supervising and writing the manuscript.

\section{Conflict of Interest Declaration}

The authors declare that there is no conflict of interests regarding the publication of this manuscript.

\section{References}

Arhire, L.I., Mihalache, L. \& Covasa, M., 2019. Irisin: A hope in understanding and managing obesity and metabolic syndrome. Front. Endo. 10, 524. DOI: 10.3389/fendo.2019.00524

Aydin, S., 2013. Multi-functional peptide hormone NUCB2/nesfatin-1. Endocrine 44(2), 312-325.

Aydin, S., 2014. Three new players in energy regulation: Preptin, adropin and irisin. Peptides 56, 94-110. DOI: 10.1016/j.peptides.2014.03.021

Banerjee, S. \& Chaturvedi, C.M., 2015. Nesfatin-1: Localization and expression in avian gonads and its modulation by temporal phase relation of neural oscillations in female Japanese quail Coturnix coturnix japonica. Gen. Comp. Endo. 224, 205-215. DOI: 10.1016/j.ygcen.2015.08.016

Blake, I.P., 1993. Methods of using poultry waste residues. International Poultry Congress 93, Istanbul. Pp. $106-107$.

Blüher, S., Panagiotou, G., Petroff, D., Markert, J., Wagner, A. \& Klemm T., Filippaios, A., Keller, A. \& Mantzoros, C.S., 2014. Effects of a one-year exercise and lifestyle intervention on irisin, adipokines, and inflammatory markers in obese children. Obesity 22(7),1701-8. DOI: 10.1002/oby.20739

Boström, P., Wu, J., Jedrychowski, M.P., Korde, A., Ye, L., Lo, J.C., Rasbach, K.A., Boström, E.A., Choi, J.H., Long, J.Z., Kajimura, S., Zingaretti, M.C., Vind, B.F., Tu, H., Cinti, S., Højlund, K., Gygi, S.P. \& Spiegelman. B.M., 2012. A PGC1-[a]-dependent myokine that drives brown-fat-like development of white fat and thermogenesis. Nature 48(7382): 463-8. DOI: 10.1038/nature10777

Cameron, J.L., Helmreich, D.L. \& Schreihofer, D.A., 1993. Modulation of reproductive hormone secretion by nutritional intake: Stress signals versus metabolic signals. Hum. Reprod. 8, 162-167. DOI: 10.1093/humrep/8.suppl_2.162

Çatlı, G., Olgaç, Dündar, N. \& Dündar, B.N., 2014. Adipokines in breast milk: An update. J. Clin. Res. Pediatr. Endo. 6 , 192-201. DOI: 10.4274/jcrpe.1531

Cetinkaya, H., Karagöz, B., Bilgi, O., Ozgün, A., Tunçel, T., Emirzeoğlu, L., Top, C. \& Kandemir, E.G., 2013. Nesfatin-1 in advanced lung cancer patients with weight loss. Regul. Pept. 181, 1-3 DOI: 10.1016/j.regpep.2012.11.005

Cisse, R.S., Freeman, M.E. \& Davis, A. J., 2012. Ovarian mRNA expression of nesfatin and visfatin in fed and fasted broiler breeder hens. Poultry Science Association. 101st Annual Meeting. University of Georgia, Athens.

Gonzalez, R., Kerbel, B., Chun, A. \& Unniappan, S., 2010. Molecular, cellular and physiological evidences for the anorexigenic actions of nesfatin-1 in goldfish. PloS One 5, e15201. DOI: 10.1371/journal.pone.0015201

Haghshenas, R., Jafari, M., Ravasi, A., Kordi, M., Gilani, N., Shariatzadeh, M., Hedayati, M. \& Rahimi, M., 2014. The effect of eight weeks endurance training and high-fat diet on appetite-regulating hormones in rat plasma. Iran $\mathrm{J}$. Basic Med. Sci. 17, 237-43.

Havel, P.J., 2004. Update on adipocyte hormones: Regulation of energy balance and carbohydrate/lipid metabolism. Diabetes 53, 143-151. DOI: 10.2337/diabetes.53.2007.s143

Inci, H., Çelik, Ş., Söğüt, B., Şengül, T., Şengül, A.Y. \& İlkaya, M., 2020. Rearing system effects on live weight gain of Large White turkeys. S. Afr. J. Anim. Sci. 840-846. DOI: sajas.v50i6.10

Juge-Aubry, C.E., Somm, E., Giusti, V., Pernin, A., Chicheportiche, R., Verdumo, C., Rohner-Jeanrenaud, F., Burger, D., Dayer, J-M. \& Meier, C.A., 2003. Adipose tissue is a major source of interleukin-1 receptor antagonist: Upregulation in obesity and inflammation. Diabetes 52, 1104-1110. DOI: 10.2337/diabetes.52.5.1104

King, P.J., 2005. The hypothalamus and obesity. Curr. Drug Targets 6, 225-240. DOI: 10.2174/1389450053174587

Könczöl, K., Pinter, O. \& Ferenczi, S., Varga, J., Kovács, K., Palkovits, M., Zelena, D. \& Tóth, Z.E., 2012. Nesfatin-1 exerts long-term effect on food intake and body temperature. Int. J. Obes. 36, 1514-1521. DOI: 10.1038/ijo.2012.2 
Li, Q.C., Wang, H.Y., Chen, X., Guan, H.Z. \& Jiang, Z.Y., 2010. Fasting plasma levels of nesfatin-1 in patients with type 1 and type 2 diabetes mellitus and the nutrient-related fluctuation of nesfatin-1 level in normal humans. Regul. Pept. 159, 72-7. DOI: 10.1016/j.regpep.2009.11.003

Li, X., Fang, W., Hu, Y., Wang, Y. \& Li, J., 2015. Characterization of fibronectin type III domain-containing protein 5(FNDC5) gene in chickens: Cloning, tissue expression, and regulation of its expression in the muscle by fasting and cold exposure. Gene 570, 221e229. DOI: 10.1016/j.gene.2015.06.022

Lopez-Legarrea, P., de la Iglesia, R., Crujeiras, A., Pardo, M., Casanueva, F.F., Zulet, M.A. \& Martinez, J.A., 2014. Higher baseline irisin concentrations are associated with greater reductions in glycemia and insulinemia after weight loss in obese subjects. Nutr. Diabetes 4, e110. https://doi.org/10.1038/nutd.2014.7

McDougal, T., 2020. Expensive feed pushes UK turkey production costs up. Poultry World 30 September 2020.

Mirzaei, K., Hossein-Nezhad, A., Keshavarz, S.A., Koohdani, F., Eshraghian, M.R. \& Saboor-Yaraghi, A.A., Hosseini, S., Chamari, M., Zareei, M. \& Djalali, M., 2014. Association of nesfatin-1 level with body composition, dietary intake and resting metabolic rate in obese and morbid obese subjects. Diabetes Metab. Syndrome. Clin. Res. Rev. 9(4), 292-298. DOI: 10.1016/j.dsx.2014.04.010

Mohan, H., Ramesh, N., Mortazavi, S., Le, A., Iwakura, H. \& Unniappan, S., 2014. Nutrients differentially regulate nucleobindin-2/nesfatin-1 in vitro in cultured stomach ghrelinoma (MGN3-1) cells and in vivo in male mice. PLoS One, 9(12): e115102. DOI: 10.1371/journal.pone.0115102

Oh-I, S., Shimizu, H., Satoh, T., Okada, S., Adachi, S., Inoue, K., Eguchi, H., Yamamoto, M., Imaki, T., Hashimoto, K., Tsuchiya, T., Monden, T., Horiguchi, K., Yamada, M. \& Mori, M., 2006. Identification of nesfatin-1 as a satiety molecule in the hypothalamus. Nature 443, 709-12. DOI: $10.1038 /$ nature05162

Price, T.O., Samson, W.K., Niehoff, M.L. \& Banks, W.A., 2007. Permeability of the blood-brain barrier to a novel satiety molecule nesfatin-1. Peptides 28, 2372-2381. DOI: 10.1016/j.peptides.2007.10.008

Richard, D. \& Baraboi, D., 2004. Circuitries involved in the control of energy homeostasis and the hypothalamic-pituitaryadrenal axis activity. Treatments Endo. 3, 269-277. DOI: 10.2165/00024677-200403050-00001

Roca-Rivada, A., Castelao, C., Senin, L.L., Landrove, M.O., Baltar, J., Crujeiras, A.B., Seoane, L.M., Casanueva, F.F. \& Pardo, M., 2013. FNDC5/irisin is not only a myokine, but also an adipokine. PLoS One 8, 6056. DOi: 10.1371/journal.pone.0060563.

Shimizu, H., Oh-I, S., Hashimoto, K., Nakata, M., Yamamoto, S., Yoshida, N., Eguchi, H., Kato, I., Inoue, K., Satoh, T., Okada, S., Yamada, M., Yada, T. \& Mori, M., 2009. Peripheral administration of nesfatin-1 reduces food intake in mice: The leptin-independent mechanism. Endo. 150, 662-671.

Shousha, S., Kirat D. \& Naso, T., 2015. Effect of central and peripheral nesfatin-1 on food intake in Japanese quail. Amer. Assn. Sci. Tech. J. Biol. 1(1), 1-9.

Spiegelman, B.M. \& Flier, J.S., 2001. Obesity and the regulation of energy balance. Cell 104, 531-543. DOI: 10.1016/s0092-8674(01)00240-9

Steiner, J., LaPaglia, N., Kirsteins, L., Emanuele, M. \& Emanuele, N., 2003. The response of the hypothalamic-pituitarygonadal axis to fasting is modulated by leptin. Endocr. Res. 29, 107-117. DOI: 10.1081/erc-120022292

Stengel, A., Goebel, M., Yakubov, I., Wang, L., Witcher, D. \& Coskun, T., Taché, Y., Sachs, G. \& Lambrecht, N.W.G., 2009. Identification and characterization of nesfatin-1 immunoreactivity in endocrine cell types of the rat gastric oxyntic mucosa. Endo. 150, 232-238. DOI: 10.1210/en.2008-0747

Stengel, A., Goebel-Stengel, M. \& Wang, L., Kato, I., Mori, M. \& Taché, Y., 2012. Nesfatin-1 (30-59) but not the N- and C-terminal fragments, nesfatin-1 (1-29) and nesfatin-1 (60-82) injected tracerebroventricularly decreases dark phase food intake by increasing inter-meal intervals in mice. Peptides 35, 143-148. DOI: 10.1016/j.peptides.2012.03.015

Tsuchiya, T., Shimizu, H., Yamada, M., Osaki, A., Oh-I, S. \& Ariyama, Y., Takahashi, H., Okada, S., Hashimoto, K., Satoh, T., Kojima, M. \& Mori, M., 2010. Fasting concentrations of nesfatin-1 are negatively correlated with body mass index in non-obese males. Clin. Endo. 73 (4), 484-90. DOI: 10.1111/j.1365-2265.2010.03835.x

Unniappan, S. \& Peter R.E., 2005. Structure, distribution and physiological functions of ghrelin in fish. Comp. Biochem. Phys., Part A, 140, 396-408. DOI: 10.1016/j.cbpb.2005.02.011

Varricchio, E., Russolillo, M.G., Russo, F., Lombardi, V., Paolucci, M. \& Maruccio, L., 2014. Expression and immunohistochemical detection of nesfatin-1 in the gastrointestinal tract of Casertana pig. Acta Histochem. 116, 583-587. DOI: 10.1016/j.acthis.2013.11.006

Volkoff, H., Canosa, L.F., Unniappan, S., Cerda-Reverter, J.M., Bernier, N.J., Kelly, S.P. \& Peter, R.E. 2005. Neuropeptides and the control of food intake in fish. Gen. Comp. Endo. 142, 3-19. http://dx.doi.org/10.1016/j.ygcen.2004.11.001

Wernecke, K., Lamprecht, I. \& Jöhren, O., Lehnert, H. \& Schulz, C., 2014. Nesfatin-1 increases energy expenditure and reduces food intake in rats. Obesity $22,1662-1668$. DOI: $10.1002 / o b y .20736$ 